\title{
Erratum to: Robotic-assisted laparoscopic versus open lateral lymph node dissection for advanced lower rectal cancer
}

Tomohiro Yamaguchi $^{1}$ - Yusuke Kinugasa ${ }^{1}$ - Akio Shiomi ${ }^{1} \cdot$ Hiroyuki Tomioka $^{1}$. Hiroyasu Kagawa ${ }^{1}$

Published online: 20 October 2015

(c) Springer Science+Business Media New York 2015

\section{Erratum to: Surg Endosc}

DOI 10.1007/s00464-015-4266-y

In the eighth line of Reference 2, "guidelines 201" should be changed to "guidelines 2010".

The online version of the original article can be found under doi:10.1007/s00464-015-4266-y.

Tomohiro Yamaguchi

t.yamaguchi@scchr.jp

1 Division of Colon and Rectal Surgery, Shizuoka Cancer Center Hospital, 1007 Shimonagakubo, Nagaizumi-cho,

Sunto-gun, Shizuoka 411-8777, Japan 